\title{
ЄРУСАЛИМСЬКИЙ УСТАВ ХV СТОЛІТТЯ У КОЛЕКЦІЇ НАЦІОНАЛЬНОГО МУЗЕЮ У ЛЬВОВІ ІМЕНІ АНДРЕЯ ШЕПТИЦЬКОГО
}

\author{
Jerusalem Typikon of the 15th Century from the Collection \\ of the Andrey Sheptytskyi National Museum in Lviv
}

\author{
Stanislav Voloshchenko
}

DOI: 10.17846/CL.2019.12.1.102-115

\begin{abstract}
VOLOSHCHENKO, Stanislav. Jerusalem Typikon of the 15th Century from the Collection of the Andrey Sheptytskyi National Museum in Lviv. The article is dedicated to research of the oldest survived Cyrillic copy of Jerusalem Typikon of the last third of the 15th century. The author investigates the problem of its dating, localization of its origin and use. The paper also lists the names of the owners and describes the transfer of the manuscript from Russia to Ukrainian Lviv. The ignorance of the codex by researchers and a lack of publications prompted this scientific study based on a codicological analysis of the external and internal features of the manuscript with methods of the auxiliary sciences of history. The paper argues that the codex is a complex artifact of culture and history.
\end{abstract}

Keywords: Jerusalem Typikon, 15th century, manuscript, codicology, Cyrillic codex, collection, Andrey Sheptytskyi National Museum in Lviv

\begin{abstract}
Abstrakt: VOLOSHCHENKO, STANISLAV. Jeruzalemský zákonník $z$ 15. storočia $v$ zbierke Národného múzea vo Lvove Andreja Šeptyckého. Článok je venovaný kodikologickému výskumu najstaršieho zachovávaného cyrilického spisu na Ukrajine známeho pod názmom Jeruzalemský zákonník, ktorý pochádza z poslednej tretiny 15. storočia. Skúmaná je problematika datovania rukopisnej pamiatky, lokalizácie, vznik a používanie i identifikácia jej majitelov. Interpretuje sa aj prenos pamiatky z Ruska do ukrajinského Lvova. Absencia dostatočného vedeckého spracovania ohladom tohto kódexu podnietila výskum, ktorý sa zakladá na kodikologickej štúdii vonkajších a vnútorných parametrov rukopisu ako komplexného kultúrneho a historického produktu, pričom sa využíva široké spektrum historicko-filologických disciplín.
\end{abstract}

Klúčové slová: Jeruzalemský zákonník, 15. storočie, rukopis, kodikológia, cyrilický kódex, zbierka, Národné múzeum Andreja Šeptyckého vo L’vove

Кириличні кодекси богослужбовго характеру середньовічного та раннього нового часу одне із вагомих джерел до загальної історії, філології, культурології та літургіки. Унікальність кожної такої рукописної пам'ятки проливає світло на особливості історї культури попередніх поколінь, їх уявлень, переживань, ментальності, ставлення до Бога та оточуючих, історії повсякдення духовних осіб і мирян, культури створення книг, ïx читання та зберігання. 3 точки зору літургіки церковні книги подають відомості про 
розвиток богослужіння, появу нових літургічних практик і зникнення або трансформацію попередніх, а також інформують про локальні богослужбові традиції.

Коло моїх наукових зацікавлень становлять кириличні списки Уставу церковного Єрусалимського (Церковний Устав, Єрусалимський Устав, Типікон) ${ }^{1}$ збережені в Україні, які відносяться до книг богослужбового характеру. На сьогоднішній день мені вдалося віднайти у зібраннях українських наукових бібліотек і музейних фондах 60 списків Єрусалимських Уставів XV - XVII ст.

Однією із найдавніших колекцій кириличних манускриптів України є збірка Національного музею у Львові імені Андрея Шептицького (далі NML). Сам Музей заснований у 1905 р., спершу як приватна колекція митрополита Андрея Шептицього під назвою “Церковний музей”, а з 1913 р. переданий митрополитом у дар українському нарові і від того часу іменується як “Національний музей у Львові" (Sydor 2015, 378; Heletovych $2015,404)$. Фондове зібрання відділу рукописів і стародруків NML станом на 1 січня 2014 p. налічує понад 11 тисяч 483 одиниці збереження, серед яких кириличні рукописи XII - XIX ст. становлять 3 тисячі 814 одиниць збереження і $є$ однією з найцінніших зібрань в Україні (Zinchenko 2015, 452).

Попри унікальність музейного артефактів NML, колекція Єрусалимських Уставів, яка складається із 15 кодексів, - маловивчена, атрибуції книг визначені приблизно та поверхнево, не існує їх повних кодикологічних описів і достатніх атрибуцій. Ці рукописні пам'ятки не введені до наукового обігу та досі не стали предметом окремих студій.

Описуючи Єрусалимські Устави із збірки NML, мою увагу привернув невеликий за форматом кодекс переписаний на 435 f. (NML, c. MC, n. u. 853). У фондово-обліковій документації Музею, укладеній на початку XX ст., рукопис записаний під інвентарним номером “Q 128” як Устав церковної служби. Книга датована там кінцем XVI ст. Також у документації йдеться, що рукопис в оправі 3 дошок і шкіри. Проте, перші візуальні обстеження книги, пов'язані із аналізом письма та почерку, особливостей оздоблення, організації сторінки і філігранологічного вивчення паперу, піддали сумніву вище вказане датування.

Тому завдання мого дослідження полягає у встановленні більш точної дати іiі створення, з'ясуванні історії побутування та визначенні регіону виготовлення книги. Дослідженя базується на вивченні зовнішніх та внутрішніх кодикологічних параметрів пам’ятки, які передбачають встановлення об’єму кодексу, формули зшитків й аркушів, особливостей проставлення сигнатур зшитків і фоліації, формату книги, дослідженні паперу, організації строрінок, системи правок тексту, вивченні типу письма та почерку, художнього оформлення, змісту рукопису, матеріалу, конструкції та оздоблення оправи, а також аналізі стану збереженості кодексу.

Відомості про історію надходження рукопису до фондів NML вдалося дізнатися частково. Єдиним джерелом, яке відповіло на це запитання, послугувала паперова друкована наліпка прямокутної форми на приклейній частині нижнього форзаца із написом чорнилом “№ 325 / Большаков / 2304”. Очевидно йдеться про відомого антиквара

1 Устав церковний Єрусалимський визначав слад, порядок і чин звершення церковних богослужінь добового кола та місячного, богослужінь Чотиридесятниці та П’ятидесятниці, а також містив правила стосовно монашого життя. За своїм характером належить до церковно-дисциплінарного жанру, його тексти не читаються у часі звершення служб, проте у них вказується порядок читань текстів із Октоїха, Мінеї, Тріодей, книг Старого та Нового Заповітів, Часослова та інших богослужбових книг у залежності від особливостей тої чи іншої служби (Diachenko 1993, 763; Ivanova 2016, 37; Frys 2003, 58). 
Большакова та облікові номери рукопису у його збірці. Мені вдалось відшукати осіб 3 прізвищем Большаков і які 6 мали стосунок до давніх книг. Одним із представників цього роду був Тихон Большаков (1794 - 1863) - московський антиквар, колекціонер і засновник династії антикварів-бібліофілів (Rykov Iurii 2002, 669). Рукопис очевидно належав або самому Т. Большакову, або ж його нащадкам - сину Сергію (1842 - 1906) та внукові Миколаю Сергійовичу (Katagoshchina 2005; Zinchenko 2015, 444). Достеменно не відомо у якому році досліджуваний кодекс потрапив із Москви до Львова та хто його точно придбав. Можливо цю місію міг виконати перший очільник NML (1905 - 1952) Іларіон Свєнціцький (1876 1956), який був у Москві 1905 р. у справах інституції (Sydor 2015, 392, 394).

Єрусалимсъкий Устав спершу інвентаризований під номером Q 128, у якому літера “Q” означала формат блоку - у четверту частину аркуша (in quarto чи $4^{\circ}$ ), а цифра “ $128^{\text {” }}$ - номер у фондовій групі збереження. Цей шифр проставлено чорнилом на приклейній частині верхнього форзаца та без літери “Q” посередині верхнього берега f. 1r. Також $є$ номер із книги надходжень “245” з топографічним номером на тому ж форзаці та вписаний чорнилом на корінці. На форзаці є ще написи олівцем “70/20” і на закладці-регістрі, розміщеній на зовнішньому боці вільного аркуша верхнього форзаца “20/15”, записаного теж олівцем. Можливо, ці номери проставлені попередніми власниками - Большаковими. У рукописі уміщено відтиски музейного штампу овальної форми чорного кольору “НАЦІОНАЛЬНИЙ МУЗЕЙ ВО ЛЬВОВІ ІМ. МИТР. АНДР. ШЕПТИЦКОГО”, розміщені на f. 1r, 124r, 191r, 248v, 287r, 357r, 435v. Обліковий шифр Музею “Q 128” був замінений на “Ркк-853", де "Ркк” означає рукопис кириличний (Manuscripts cyrillic, abbreviated to MC). Він записаний олівцем на вільних аркушах верхнього та нижнього форзаців, а також чорнилом на наліпці посередині корінця.

Текст кодексу переписано церковнослов'янською мовою на 435 f. Кількість зшитків, а також і чисельність аркушів у кожному визначити проблематично. Книжковий блок кілька разів перешивався, останній раз на початку XX ст., тому втрачено первинне шиття та розташування аркушів у зшитки. Сигнатури (нумерація зшитків) повністю зрізані при останньому обрізуванні блоку рукопису. Фрагмент від сигнатури зберігся частково лише на f. 245r у вигляді титла. Найочевидніше, що нумерація зшитків проставлялася кириличними цифрами коричневим атраментом посередині нижнього берега аркуша. У кодексі дві фоліації: одна записана у XVIII ст., а інша у 2017 р. Перша проставлена кириличними цифрами під титлом чорнилом у зовнішньому нижньому куті аркушів із f. 1r по f. 434r. При обрахунку аркушів було допущено помилку - f. 32r було пронумеровано як f. 33r. Друга ж фоліація, з врахуванням помилки, проставлена арабськими цифрами олівцем у зовнішньому верхньому куті аркушів із f. $1 \mathrm{r}$ по f. $435 \mathrm{r}$.

Відповідь про приблизний час виготовлення пам'ятки, значною мірою, надає філігранологічний аналіз паперу. Досліджуваний Єрусалимський Устав переписаний на ганчір'яному папері білого кольору форматом in quarto, тобто у четверту частину аркуша $\left(4^{\circ}\right)$. Його розмір тепер становить близько 180 мм завдовжки і 123 мм завширшки. За моїми спостереженнями, папір книги варто відносити до останньої третини XV cт. Під час філігранознавчого дослідження виявив два варіанти зображення “голови теляти”. У першому варіанті “голова теляти” із квіткою з шістьма пелюстками. Це зображення зустрічається на більшій частині аркушів кодексу - 190 аркушах (у проміжку між f. 4 i f. 387). Виявлений водяний знак віднайдений у електронному каталозі філіграней Герхарда Піккарда, тотожний зображенню під номером 70113 і датується 1473 p. (Piccard Online, 70113). На інших 23 аркушах (у діапазоні f. 390 i f. 434) “голова теляти” доповнена короною та квіткою з п’ятьма пелюстками. У того ж таки Г. Піккарда ця філігрань датована 1476 p. під № 68160 (Piccard Online, 68160). Місце виготовлення паперу із зображенням останньої 
філіграні Г. Піккард відносить до італійської Брешії (Brescia), розташованої на півночі країни. Дослідження водяних знаків паперу дозволило піддати критиці існуюче датування книги кінцем XVI ст., натомість віднести час створення кодексу до 70-х pp. XV ст.

Дзеркало запису тексту на сторінці складає 160 х 90 мм із 22-а рядками. Висота рядкових літер становить 2 мм, розмір виносних елементів рядкових літер вгору $2-2,5$ мм, а вниз 2 - 6 мм. Ширина вузьких літер “о”, “а”, “с", “в” коливається від 1,5 до 2 мм, а широких “м”, “т”, “ш”, “щ”, “я” складає від 4 до 5 мм. Міжрядковий інтервал завширшки у понад 4 мм. У середньому в рядках вписано від 25 до 30 літер. На f. 74v i f. 429r завершення розділів основного тексту спадає згори до низу у V-подібній формі - у вигляді скорочених з обох боків 12 рядків. Текст кодексу компактно поділений переписувачем на рубрики, що дозволяє зручному користуванню та уважності при читанні. Піклування про читача також передбачало й систему індексів на зовнішніх берегах аркушів у вигляді позначень глав, умовних скорочень і символів. Колонтитули пізнішого часу - писані, найочевидніше, y XVIII ст. скорописом коричневим атраментом на f. 76r - 295r посередині верхнього берега. На цих аркушах переписано календарну частину Єрусалимського Уставу - Місяцеслов.

Манускрипт переписаний півуставом останньої третини XV ст., схожим до почерку Єрусалимського Уставу XV ст. із колекції Троїце-Сергієвої лаври (RSL, c. 304.I. TSL, n. u. 239). Літери виведені переписувачем середніх розмірів, виписані каліграфічно, прямо, але із легким нахилом уліво. Почерк основної частини Уставу один і розташований нa $\mathrm{f} .1 \mathrm{r}-429 \mathrm{r}$. Текст переписаний світло-коричневим атраментом, а окремі елементи кіновар'ю. Аркуші наприкінці блоку із номерами f. 430r - 435v переписані іншою рукою темно-коричневим атраментом і кіновар'ю. Храктерною ознакою іншого переписувача $є$ більш видовжені літери із легким нахилом уліво.

Увесь текст рукописного кодексу рясніє правками основного переписувача. Вони розташовані як на зовнішніх берегах, так і на нижніх. При цьому застосовано різноманітні види позначення посилань: найчастіше у вигляді вертикальної риски із двома крапками “|:” або й трьома, хрестика в колі і без нього, чи просто крапки, трьох крапок y V-подібній формі або символа схожого до літери “C” із трьома крапками і символа схожого до обернутої вліво літери “C” із тою ж кількістю крапок. Також трапляється посилання, яке нагадує латинську літеру “V” із двома крапками угорі. Виправлення тексту передбачало, що в рядку, у якому було пропущено літеру, слово чи навіть речення ставився один із перерахованих покликів біля місця пропуску. На берегах ставився той же символ і вписувалося пропущене. Є кілька випадків, коли переписувач просто дописував пропущене у міжрядді чи закреслював зайве. Інші ж помилки у тексті на f. 116r, 195r, 276v i 305v писар виправив за допомогою стирання атраменту з паперу. Подібна практика застосовувалися переписувачами книг на пергаменті, оскільки поверхня цього матеріалу сприяла видаленню погрішностей копіювальника таким способом. У випадку з папером такі виправлення трапляються рідко, бо залишаються контури літер і символів, а також пошкодження матеріалу є надто помітними. Можливо переписувач Єрусалимського Уставу практикувався на переписуванні кодексів на пергаменті та був професійним писарем. Так чи інакше він відповідально підійшов до праці - після завершення копіювання книги усе записане звірив все аж до застосування знаків пунктуації.

Власники-користувачі пам'ятки у XIX ст. залишили на окремих аркушах закладкирегістри, розташовані на зовнішніх берегах f. 49r, де уміщена глава 50 “Уставу церковній службі” та іiі підрубрика “Про малий празник”, а на f. 178r - місяцесловне послідування, щодо служби на 5 січня. На f. 306r закладка міститься на приписах, які стосуються читань паремій тропарів, що відбуваються під час богослужіння Часу 6 у середу сиропустної седмиці. Я вважаю, що наявність цих регістрів $є$ свідченням про особливу затребуваність 
або інтерес у попередніх власників саме до згаданих частин кодексу, на яких знаходяться ці закладки.

Рукопис оздоблений лише однією заставкою на f. 1r. (Fig. 1). Вона прямокутної форми плетінчастого типу, розміром 66 х 91 мм. Заставка складається з восьми кіл, розташованих у три ряди, і десяти півкіл, розміщених так само. Між колами і півколами вписано сім ромбів, а у кутах рослинні розгалуження. Заставка виписана кіновар'ю, жовтою та темнозеленою барвами. Заголовки Місяцеслова, Послідувань Чотиридесятниці та П'ятидесятниці виписані в’яззю кіновар'ю, інші ж писані великими літерами півуставом і також кіновар'ю. Заголовні літери та перші букви речень у тексті кіноварні. Індекси, посилання та інші позначки на берегах писані кіновар'ю та коричневим атраментом.

Текст кодексу MC-853 із збірки NML можна умовно розділити на дві частини основну та додаткову. Основна частина книги призначена для пояснення та регламентації різноманітних богослужінь церковного року і складається із самого Уставу церковної служби, Місяцеслову (календарна частина), послідуваннь у період Чотиридесятниці (богослужіння від Неділі про митаря та фарисея до п’ятниці шостої неділі Великого посту), П’ятидесятниці (служби від Лазаревої суботи до Неділі всіх святих) та ПетроПавлівського посту (богослужіння від понеділка 9 Неділі після Великодня до 29 червня за старим стилем).

Розділ Уставу церковної служби досліджуваного рукопису складається із 67 глав, які можна поділити на три групи за джерелами походження. Першу групу становлять глави з номерами 1 - 16, які присвячені загальному порядку богослужінь із обгрунтувальними статтями до них і $є$ оригінальною частиною тексту. До другої групи належать глави 17 - 40 узяті із другої частини Маркових глав ${ }^{2}$. Третя група глав $45-67$, за твердженням російського дослідника XIX ст. Івана Мансвєтова (Mansvetov 1885, 276), походять із Тактикона Никона Чорногория ${ }^{3}$. Мова йде про дисциплінарні приписи, які стосуються особливостей чернечого життя, скомпоновані 3 першого Слова (глави) Никона Чорногорця. Мені вдалося точно встановити походження 9 глав. За співставленням тексту, глави із номерами 45, 47, 49, 53, 54, 56, 58, 64 і 67 (Appendix) рукопису MC-853 співвідносяться із відповідними рубриками у списках Тактиконів XVI cт. (RSL, c. 304.I. TSL, n. u. 211, 212, 213). Однак решта глав $(46,48,50$ - 52, 57, 59 - 63, 65 - 66) на разі не ідентифіковані за доступними рукописами джерелами.

Джерела написання глав 41 - 44 досі залишаються дискусійними. І. Мансвєтов висловив припущення, що вони можуть становити продовження другої частини Маркових глав.

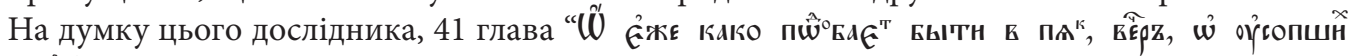

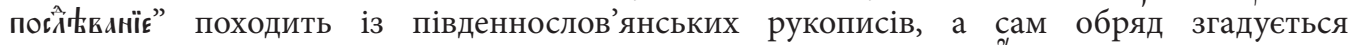

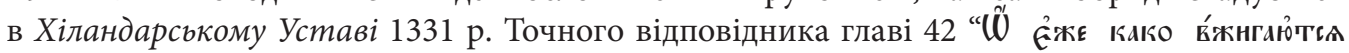

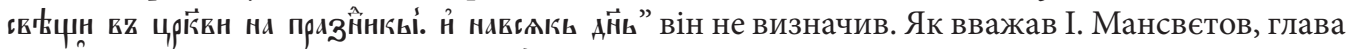

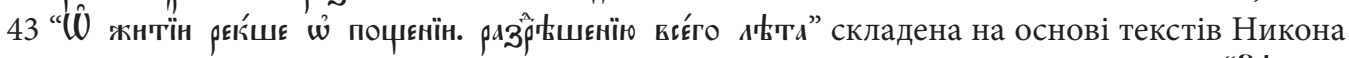
Чорногорця і послання константинопольського патріарха Миколая, а глава 44 "Rғдомо

2 Маркові глави або Глави Марка ієромонаха містять вимоги щодо порядку звершення служб у випадках збігу нерухомих церковних свят із рухомими, із днями тижневого та річного богослужбових кіл. Вказівки Маркових глав полягають у поєднанні послідувань Мінеї з послідуваннями Тріоді пісной чи Тріоді цвітної (PPBES 1913, 1557).

3 Тактикон - збірник правил, написаний монахом Никоном Чорногорцем (Дивногорцем) у кінці XI ст. Книга за своїм характером відноситься до компілятивного жанру. Вона містить 40 слів (глав), які стосуються приписів стосовно чернечого та літургійного життя, роздумів автора про Православну Церкву, про іiі потреби і виклики, а також про неправославних християн (PPBES $1913,1666)$. 
Jerusalem TyPikon OF THE 15Th Century From the COllection of the Andrey Sheptytsky National Museum in Lviv

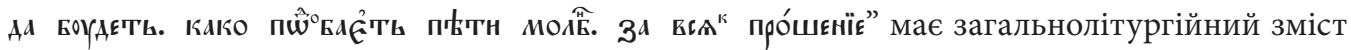
(Mansvetov 1885, 278 - 279).

У манускрипті МС-853 поруч із індексами глав 41 - 43 розташовані монограми “Фн”, які цілком вірогідно можуть читатися як скорочення від грецької форми імені Никона

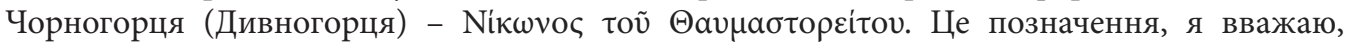
$€$ посиланням на цього автора. Воно також зустрічається навпроти цих глав у подібному вигляді в інших списках Єрусалимських Уставів XVI ст., з якими мені доводилося працювати (SL IFNUL, c. MC, n. u. 211 III; LNSL, c. ASP, n. u. 48).

Варто відзначити, що перша частина Маркових глав, які стосуються особливостей богослужінь церковного року, подані у Місяцеслові. У цій частині тексту кодексу МС-853 вдалося віднайти багато імен києво-руських святих. У вересні згадується три дати - 19 числа благовірного Федора, князя Смоленського та Ярославського (1233/1240 (?) - 1299) (96r - 97r), 20 - великомученка Михаїла Чернігівського (1179 - 1246) і боярина його Федора (f. 97r - 98r) і 25 - преподобного Сергія, ігумена Радонежського (1314/1322 (?) 1392) (f. 100r - 101r), а у жовтні одна - 29 числа день упокоєння преподобного Авраамія Богоявленського, архієпископа Ростовського (+1077) (f. 119v - 120v). Осінній цикл замикає день пам'яті преподобного Варлаама Новгородського (+1192), яке припадало на 6 листопада (f. 124r - 125r). Взимку згадується про трьох святих: 15 грудня святителя Стефана, архієпископа Сурожського (VIII ст.) (150v - 151v), 21 грудня святителя Петра, митрополита Київського (1260 (?) - 1326) (157v - 158r) і 12 лютого святителя Олексія, митрополита Київського (+1378) (205v - 206r). У другій половині квітня, 26 числа припадав празник святителя Стефана, єпископа Пермського (+1396) (247v - 248r). Особливо багатий на києво-руських святих травень. У цьому місяці зафіксовано вісім днів пам'яті цих подвижників: 2 травня перенесення мощів страстотерпців князів Бориса i Гліба (f. 249v - 250r), 3 числа успіння преподобного Феодосія Печерського (1009 (?) - 1074) (f. 250v - 251r), 14 - Ісидора Юродивого, Ростовського чудотворця (+1474) (f. 257v - 258r), 15 - святителя Iсаї, єпископа Ростовського (+1090) (f. 258r - 259v), 20 - обретіння мощів святителя Олексія, митрополита Київського (+1378) (f. 258v - 259r), 23 - обретіння мощів святителя Леонтія, єпископа Ростовського (+бл.1077) (f. 260r - 260v), 24 - преподобного Никити Стовпника, Переславського чудотворця (+1186) (f. 260v - 261r) і 28 травня день упокоєння святителя Ігнатія, єпископа Ростовського (+1288) (f. 261v). У наступному місяці лише дві згадки - 9 червня записано святкування преподобного Кирила, ігумена Білозерського (1337 - 1427) (f. 263r - 263v), а 11 числа преподобної Ольги, княгині Київської (910 - 986) (f. 264r - 264v). Замикає києво-руський календар чотири свята влітку: 1 липня перенесення мощів святителя Петра, митрополита Київського (+1326) (f. 270v 271r), 15 - рівноапостольного Володимира Великого, князя Київського (960/963 (?) - 1015) (f. $275 \mathrm{r}-275 \mathrm{v}), 24$ - страстотерпців князів Бориса і Гліба $(279 \mathrm{r}-279 \mathrm{v})$ і 26 серпня стрітення Вишгородської (Володимирської) ікони Богородиці в Москві (1395) (292v).

Завершений календар доповнювався згодом користувачами рукопису. На нижньому березі арк. 272 коричневим атраментом скорописом записано, що 5 липня треба святкувати перенесення мощів преподобного Сергія Радонежського (1422), так само записано й про два наступні свята - 7 липня Новоявлення Казанської ікони Богородиці (1579) (f. 273r) і 30 серпня день пам’яті преподобного Олександра Свірського (1448 - 1533), канонізованого y 1547 p. (f. 297r).

За допомогою фактографічної інформативності Місяцеслова, можна припустити, що досліджуваний Єрусалимський Устав був переписаний у проміжку між 1474 і 1479 pp. Адже відомо, що Ісидор Юродивий помер у 1474 р. і одразу почитався місцевою єпархією, у цьому 
ж році місцевошанованим святим став й Ісая Ростовський за урядування архієпископа Ростовського - Вассіана Рила (+1481). Ще одним підтвердженням мого датування $є$ й внесення до календаря кодексу під 1 липня - дня перенесення мощів святителя Петра, митрополита Київського, яке відбулося у цей же день 1472 р., а друге перенесення останків цього святого було 24 серпня 1479 р. Також я припускаю, що рукопис міг бути переписаний у тодішніх межах канонічної території Ростовської єпархії. Серед двадцятитрьох києво-руських святих, територіально репрезентованих різними єпикпопіями Київської та Московської митрополій, п’ять подвижників “просіяли” саме на Ростовщині. Ще одним аргументом на випрадання моєї гіпотези про ростовське походження досліджуваного списку Єрусалимського Уставу із фондів NML $€$ той факт, що власне, на Ростовщині могли почитатися до часу всецерковного святкування місцевошанований з 1474 р. святитель Ісая, єпископ Ростовський, і “народне” вшанування в якості святого щойного спочилого (1474) Ісидора Юродивого, Ростовського чудотворця.

Додаткову частину рукопису МС-853 становлять рубрики із текстами різноманітних тропарів: загальних, богородичних, іпакоїв, світильних, воскресних, повсякденних й окремим святим. Переписувач також подав прокимени воскресні та повсякденні 3 відповідними алилуаріями, повсякденних антифонів а також тексти відпустів на богослужіннях. Окрему увагу приділив деяким частинам служб Страсного тижня, навів текст Херувимської пісні у велику суботу “Да молчит всяка плоть человеча”, а під ним і традиційного - “Иже Херувимы тайно образующе”. Він подав відповідні молитви перед замішуванням хліба та над коливом (кутею). Записав також чин умивання ніг святителю чи настоятелю монастиря, який здійснюється у Страсний четвер після заамовної молитви на літургії. $Є$ також тексти припіл Великої суботи. Наприкінці кодексу переписувачем записано, як має відбуватися похорон духовенства та мирян, чин хрещення, сповіді та причастя.

Проаналізувавши основну та додаткову частини змісту кодексу, я дійшов до висновку, що список Єрусалимського Уставу із колекції NML XV ст., за класифікацією I. Мансвєтова, можна віднести до третьої редакції (Mansvetov 1885, 274 - 280).

Кодекс оправлений у дошки, поволочені шкірою (Fig. 2). Оправа виготовлена (“зібрана”) у другій половині XIX - на початку XX ст. Вона складається із різночасових елементів. Дошки і їх шкіряне покриття темно-коричневого кольору належали іншому кодексу і їх можна датувати XVIII ст. Покриття на корінці із шкіри світло-коричневого кольору XIX ст. із відтиснутим написом “СЛУЖЕБНИКЪ”. Можливо ця частина належала якомусь Служебнику, а потім іiї використали як корінець досліджуваного Єрусалимського Уставу. Шиття блоку рукопису здійснено на 3-х одинарних шнурах. Корінець книги глухий і каширований. У якості форзаців застосовано целюлозний папір білого кольору. Вони за конструкцією суцільні, а за типом кріплення - пришивні. Дошки розміром 200 x 135 x 6 мм із кантами і рантами, поволочені шкірою темно-коричневого кольору, оздобленою тисненням. Оправа має дві литі застібки на врізні пробої з шкіряними ременями XIX ст. Кришки оздоблені блінтовим (сліпим) тисненням. Тиснення на дошках збереглося погано: сюжетні зображення дійшли у затертому вигляді. На верхній кришці (Fig. 2) проглядається рамка, утворена накаткою плетеною із султанами, завширшки 14 мм. У середині внутрішнього простору розташований ромбовидний середник із рослинним орнаментом, розміром 55 х 33 мм. У внутрішніх кутах знаходяться відтиски квітчастих штампів. На нижній кришці та ж рамка, що й на верхній, однак у внутрішньому просторі вгорі та внизу розміщені горизонтальні поля без оздоблення між якими дві вертикальні смуги, утворені тою ж накаткою, що й рамка - плетеною із султанами. Рамки та смуги облямовуються та розмежовуються потрійними лініями дорожника різної 
ширини - середня ширша за бічні, завширшки до 1 і 3 мм відповідно. Подібне конструкція оправи і елементи ії оздоблення були характерними для оправ XVIII ст. Оздоблення покриття на корінці виконане за допомогою золотого тиснення - бинти віджаті з боків дорожником та рослинно-квітчастою накаткою, завширшки у 4 мм, які утворюють чотири проміжки. У другому проміжку згори відтиснуто назву книги “СЛУЖЕБНИКЂ”. У вздовж рантів відтиски ліній дорожника. За моїми спостереженнями, цій книзі “підібрали” відповідну за розмірами оправу після останнього обрізування книжкового блоку, адже ранти дошок XVIII ст. повністю співпадають із щойно обрізаним у XIX ст. блоком.

Список Єрусалимського Уставу, якому присвячено цю статтю, дійшов у неповному вигляді. Втрачено аркуші наприкінці книжкового блоку після f. 435v. На нижньому березі f. $434 \mathrm{v}$ світло-коричневим атраментом записано скорописом другої половини XVIII ст. “473 листа”. Можливо, рукопис міг складатися із понад 473 f., а втарачені аркуші були знищені вогнем. Це підтверджує закреслений і частково затертий запис XIX ст. на f. 429v, у якому йдеться, що ця книга горіла. Встановив, що f. 52r - 61v вшито у неправильному порядку, вони мали 6 розміщуватися між f. 21v i f. 22r. Окрім того, f. 2r - 6v i f. 426r - 427v відокремлені від книжкового блоку. На аркушах помітно незначні розриви і втрати паперу по краях. Рукопис із загальним поверхневим забрудненням, на більшості сторінок плями від воску, а нижні кутики вкриті жиром пальців, що є свідченням активного користування кодексом. Також $є$ плями від атраменту, іржі та клею. У верхній та нижній частині блоку, у ділянці корінця, плями від затікання водою, а також у верхній зовнішній частині. За відтінками кольорів цих плям, я дійшов до висновку, що рукопис затікав щонайменше двічі або й тричі. На аркушах виявлено ентомологічні пошкодження. Шкіряне покриття оправи забруднене, із значними втратами покривного матеріалу, розривами, тріщинами, потертостями, лущенням і також ентомологічними пошкодженнями. Кодекс зберігся без капталів. На f. 1 r - 2v i f. 428r - 435v втрати паперу по краях нарощено смужками ганчір'яного паперу білого кольору, ймовірно, перед останнім оправленням.

Здійснивши комплексне кодикологічне дослідження кириличного списку Єрусалимського Уставу із фонду кириличних рукописів відділу рукописів і стародруків Національного музею у Львові імені Андрея Шептицького, я дійшов до декількох висновків. Рукописна книга створена на теренах Ростовської єпархії Московської митрополії у 70 pp. XV ст. Книжковий блок виготовлений із ганчір'яного паперу італійського походження у четверту частину аркуша. Переважно увесь кодекс переписано однією рукою каліграфічним півуставом, можливо творець кодексу був професійним писарем і займався переписуванням книг не лише на паперовому носії, а й на пергаменті. Початок рукопису оздоблений чималою багатобарвною заставкою плетінчастого типу, текст поділений на розділи, які у свою чергу - рубриками. На берегах пам'ятки розташовані індекси глав, умовних позначень і виправлень основго тексту, за допомогою системи посилань. Текст кодексу, опісля завершення копіювання, звірявся та правився переписувачем. У процесі безпосередніх студій змісту рукописної книги дійшов до висновку, що досліджуваний

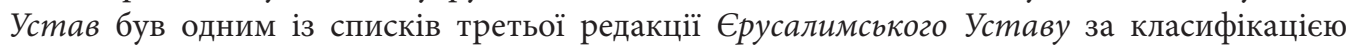
I. Мансвєтова. Унікальність джерельного фактажу, зосередженого у Місяцеслові дозволила звузити датування кодексу 1474 - 1479 рр. Рукопис активно використовувався, про що свідчать пошкодження механічного карактеру, а також різноманітні забруднення поверхні аркушів. Останній раз книга поновлювалася (реставрувалася) у ХІХ ст. під час чого й оправлено книжковий блок. До фондової колекції NML книга закуплена у московської родини антикварів Большакових на початку минулого сторіччя. 


\section{REFERENCES}

Andrey Sheptytskyi National Museum in Lviv, department of the manuscripts and old printed books (abbreviated to NML), collection (abbreviated to c.) Manuscripts cyrillic (abbreviated to MC), number of the unit (abbreviated to n. u.) 853.

Diachenko, Grigorii. 1993. Полный церковно-славянскій словарь / Григорій Дьяченко, свящ. Репр. воспроизведение изд. 1900 г. [Complete Dictionary of Church. Rep. ed. reproduction year 1900]. Moscow.

Katagoshchina, Mariia Vsevolodovna. 2005. Предпринимательская деятельность российских антикваров в конце XIX - первой трети XX века: автореферат диссертации на соискание ученой степени кандидата исторических наук: 07.00.02 [Business activities of the Russian antiquaries at the end of the 19th century - beginning of the 20th century: thesis abstract for acquiring of scientific degree of candidate of historical sciences: 07.00.02]. Moscow.

Frys, Vira. 2003. Історія кириличної рукописної книги в Україні [The History of Cyrillic Books in Ukraine]. Lviv.

Heletovych, Mariia. 2015. Внесок Митрополита Андрея Шептицького у формування збірки Національного музеюу Львові [Contribution of Metropolitan Andrey Sheptytskyi to forming a collection of the National Museum in Lviv]. In Митрополит Андрей Шептицький основник Національного музею у Львові [Metropolitan Andrey Sheptytskyi - the founder of the National Museum in Lviv] 404 - 417. Lviv.

Ivanova, Olha Andriivna. 2016. Кирилична рукописна книга XVI ст. $з$ фондів Інституту рукопису Національної бібліотеки України імені В. I. Вернадського: Історикокодикологічне дослідження. Альбом філіграней [Cyrillic Books of the 16th century from the Collection of the Institute of Manuscript of the Vernadskyi National Library of Ukraine: Studies on Historical Codicology. Album of the watermarks]. Kyiv.

Mansvetov, Ivan Danilovich. 1885. Церковный уставъ (Типикъ), его образованіе и судьба въ греческой и русской церкви [Church statue (Typikon), its creation and destiny in Greek and Russian Church]. Moscow.

Piccard Online. Wasserzeichenkartei Piccard, no 68160, no. 70113.

https://www.piccard-online.de/start.php

PPBES. 1913. Полный православный богословскій энциклопедическій словарь [Complete Orthodox Theological Encyclopedic Dictionary]. Saint Petersburg.

Rykov, Iurii Dmitrievich. 2002. Большаков [Bolshakow]. In Православная Энциклопедия [Orthodox Encyclopedia] 5. Moscow, 669 - 670.

Scientific Library of Ivan Franko National University of Lviv, department of the manuscripts, old printed and rare books of F. Maksymenko (abbreviated to SL IFNUL), collection (abbreviated to c.) Manuscripts Collection (abbreviated to MC), number of the unit (abbreviated to n. u.) 211 III.

Vasyl Stefanyk Lviv National Scientific Library of Ukraine, department of the manuscripts (abbreviated to LNSL), collection (abbreviated to c.) Anton Semenovych Petrushevych (abbreviated to ASP), number of the unit (abbreviated to n. u.) 48.

Sydor, Oleh. 2015. Національний музей у Львові в історії музейництва Галичини кінця XIX початку XX століття [National Museum in Lviv in the history of the Museums of Galicia the end of the 19th and early 20th centuries]. In Митрополит Андрей Шептицький основник Національного музею у Львові [Metropolitan Andrey Sheptytskyi - the founder of the National Museum in Lviv]. Lviv, $388-403$.

The Research Department of Manuscripts of the Russian State Library (abbreviated to RSL), collection (abbreviated to c.) 304.I. The main meeting of the library of the Trinity-Sergius 
Lavra (abbreviated to 304.I. TSL), number of the unit (abbreviated to n. u.) 239. http://old.stsl. $\mathrm{ru} /$ manuscripts/book.php?col=1\&manuscript=239.

The Research Department of Manuscripts of the Russian State Library (abbreviated to RSL), collection (abbreviated to c.) 304.I. The main meeting of the library of the Trinity-Sergius Lavra (abbreviated to 304.I. TSL), number of the unit (abbreviated to n. u.) 211, 212, 213.

http://old.stsl.ru/manuscripts/book.php?col=1\&manuscript=211.

http://old.stsl.ru/manuscripts/book.php?col=1\&manuscript=212.

http://old.stsl.ru/manuscripts/book.php?col=1\&manuscript=213.

Zinchenko, Svitlana. 2015. Збірка рукописів і стародруків Національного музею у Львові імені Андрея Шептицького [Collection of manuscripts and old printed books of the Andrey Sheptystkyi National Museum in Lviv]. In Митрополит Андрей Шептицький - основник Національного музею у Львові [Metropolitan Andrey Sheptytskyi - the founder of the National Museum in Lviv]. Lviv, $442-461$.

\begin{abstract}
SUMMARY: JERUSALEM TYPIKON OF THE 15TH CENTURY FROM THE COLLECTION OF THE ANDREY SHEPTYTSKYI NATIONAL MUSEUM IN LVIV. The article presents the results of the complex codicological research of the Cyrillic copy of the Jerusalem Typikon from the last third of the 15th century (MC-853). The document belongs to the collection of the department of manuscripts and old printed books of Andrey Sheptytskyi National Museum in Lviv which holds one of the biggest collections of the Cyrillic manuscripts in Ukraine. The codex had been bought in Moscow from the Bolshakov family of Russian antiquarians. My research interest focused on the dating of the codex, i. e. the study of the watermarks, the analysis of the factual information of the text, palaeography and elements of decorations of the manuscript. According to the watermarks study, the codex was copied in the 1470s. It was created between 1474 and 1479, and the hand, features of the decorations and corrections of the text suggest the scribe of high education and professionalism. The codex was rebounded several times in the 19th century and the original type of binding had been destroyed. The original type of signatures (drop folio) of the 15th century was made in the Cyrillic numbers in the middle of the footer in the first folio of the quire. The number of the 435 folios shows the trivial losses of the codex. The paper was produced in Italy, according to the identity of watermarks. The text of one hand is compactly organized in one column of 22 lines in a page with 25-30 letters in each line. Wide margins of the codex page were created for a system of indexes, rubrics, and notes. The main decoration of the manuscript is a headpiece in the first folio. On the basis of the textual analysis the codex belongs to the third redaction of the Cyrillic Jerusalem Typikon. The modern cover of this manuscript was recreated from two other covers from the codices of the 18th and 19th century.
\end{abstract}

Stanislav Voloshchenko, Master of History

The Old Ukrainian Book Museum

Borys Voznytskyi National Art Gallery of Lviv

N. Copernicus Street, 15a

79000 Lviv

Ukraine

stachevskiy@gmail.com 


\section{Appendix / Prílohy}

\section{Зміст Єрусалимського Уставу (МС-853) \\ Content of the Jerusalem Typikon (MC-853)}

Основна частина:

The main part:

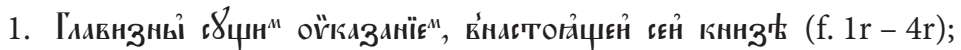

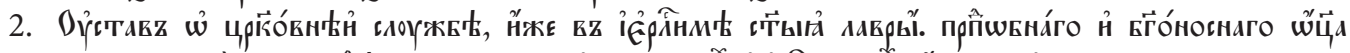

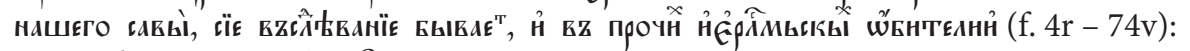

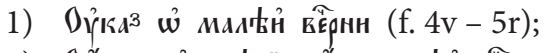

2) О人̆

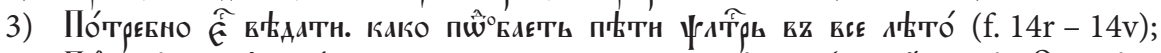

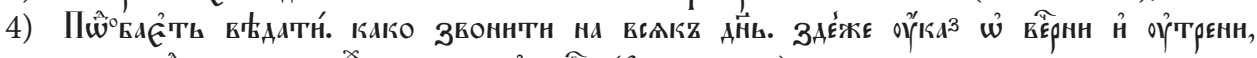

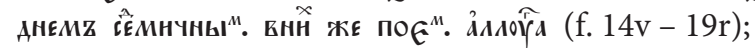

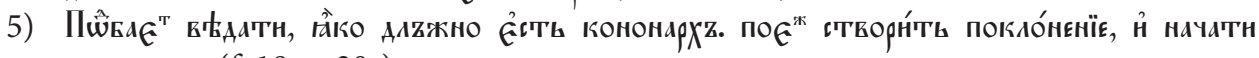
конархатн (f. 19r - 20r);

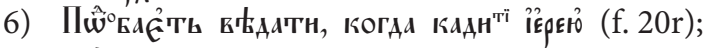

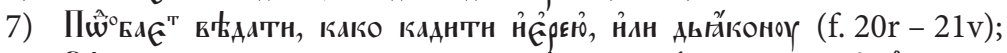

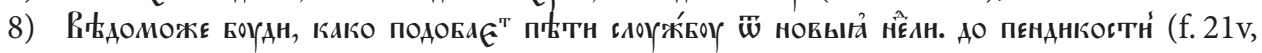
$52 \mathrm{r}$ );

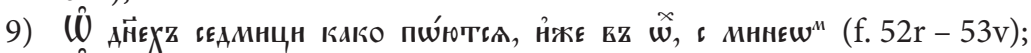

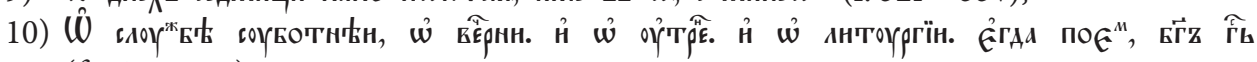
(f. $53 \mathrm{v}-54 \mathrm{v})$

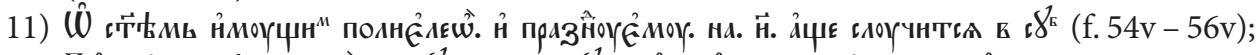

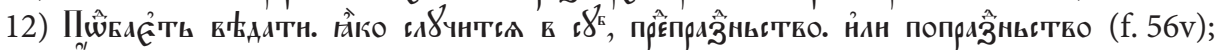

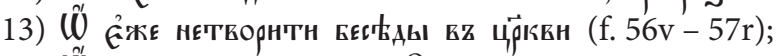

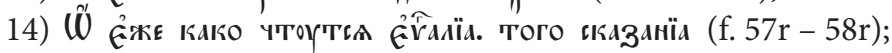

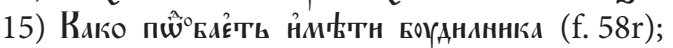

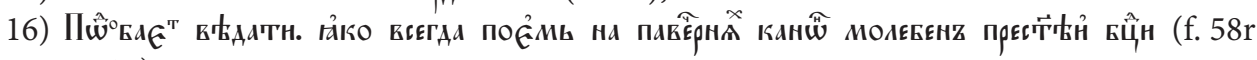
$-58 \mathrm{v})$

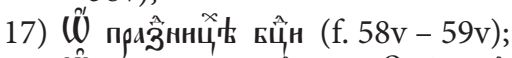

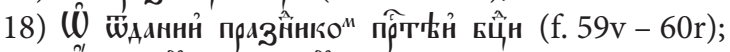

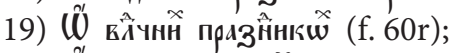

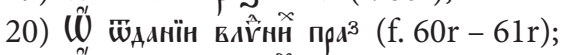

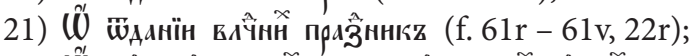

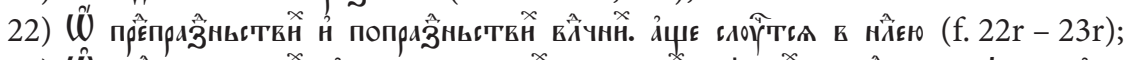

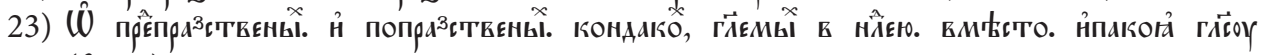
(f. 23r);

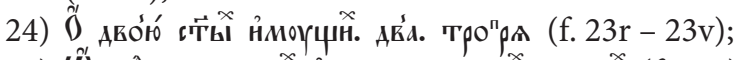

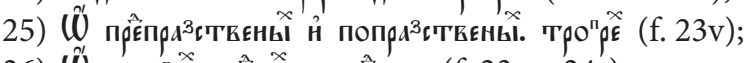

26) (И) Тр

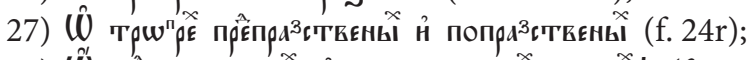

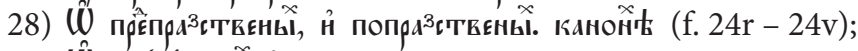

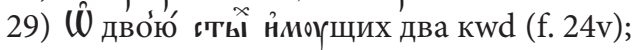




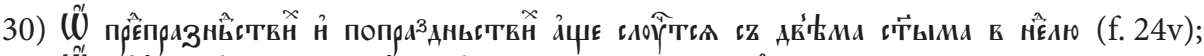

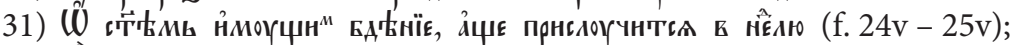

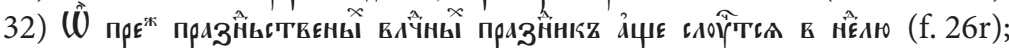

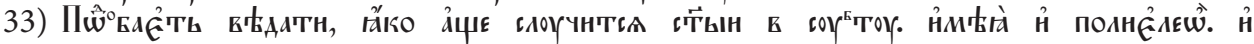

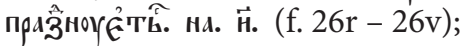

34) П Зें

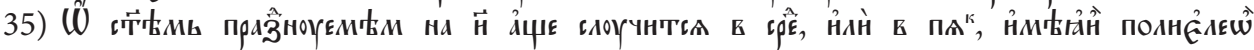
(f. 26v);

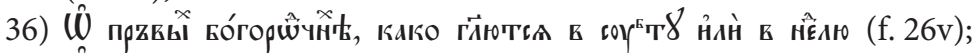

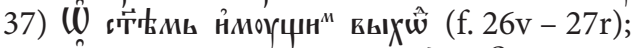

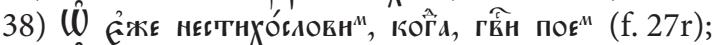

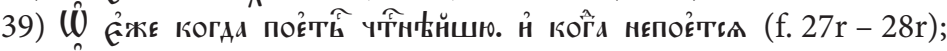

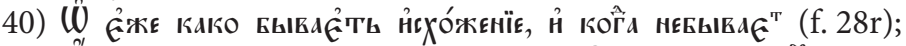

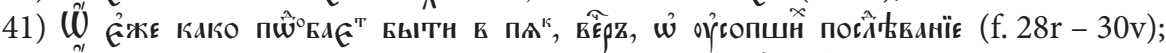

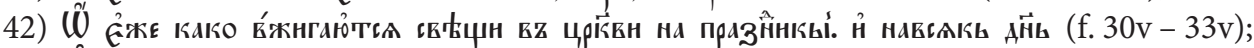

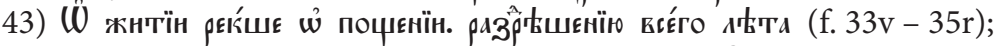

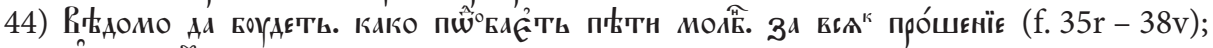

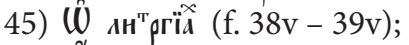

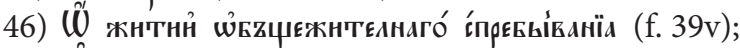

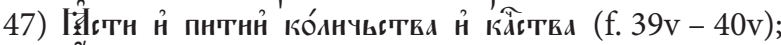

48) (О) молчаньн̈ на трапєз' $($ f. $40 \mathrm{v}-42 \mathrm{v})$;

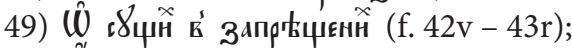

50) (Й ра

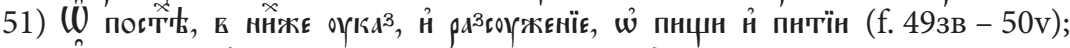

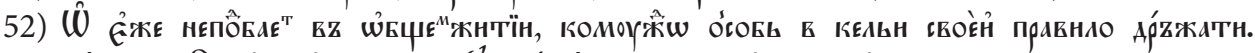

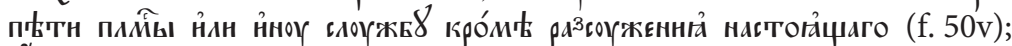

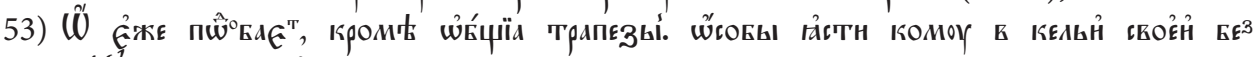

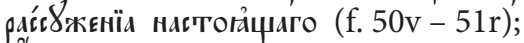

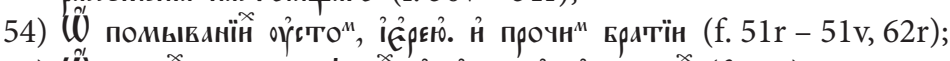

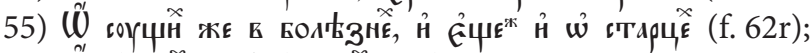

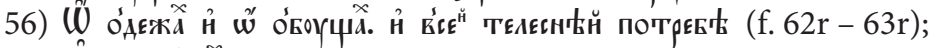

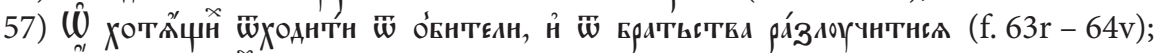

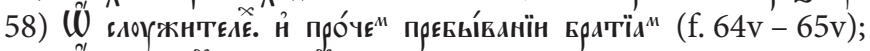

59) (Ü слоүжва тАжкКЫ (f. 65v-66v);

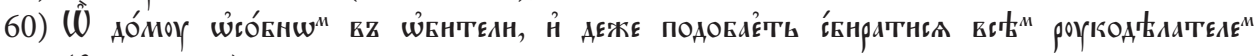
(f. $66 \mathrm{v}-67 \mathrm{r}$ );

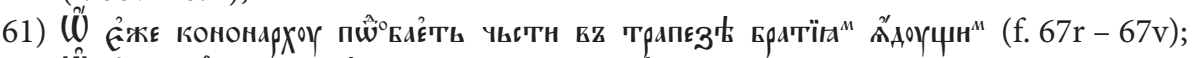

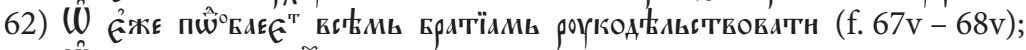

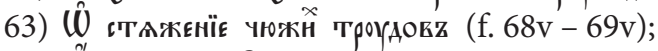

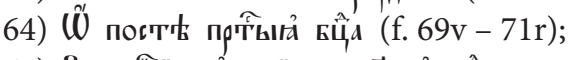

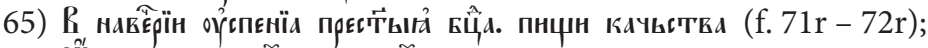

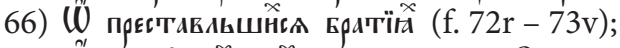

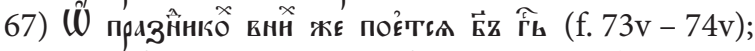

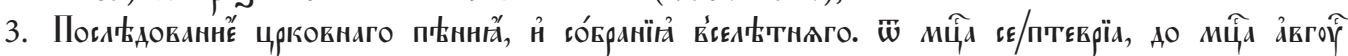
(f. $75 r-295 r$ );

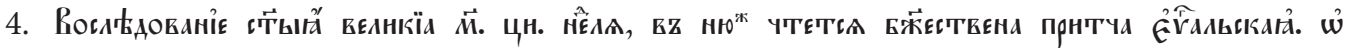

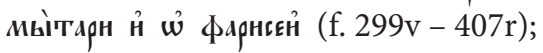




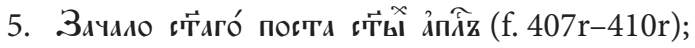

Додаткова частина:

An additional part:

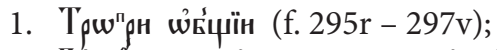

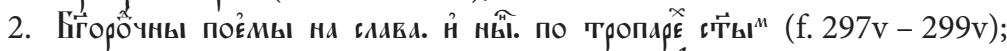

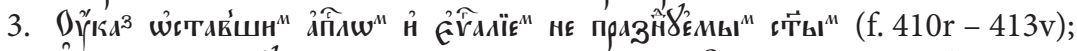

4. Н̈

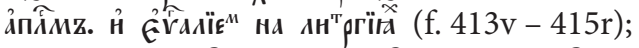

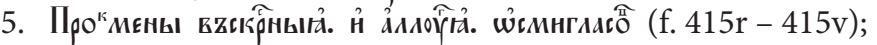

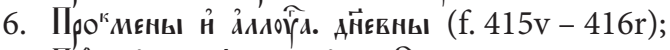

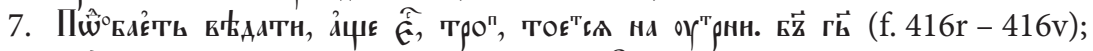

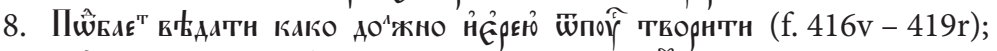

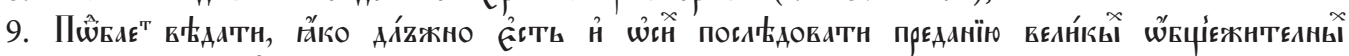

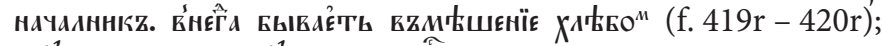

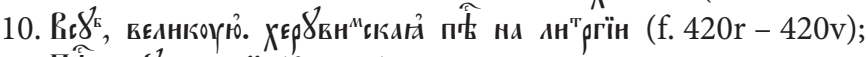

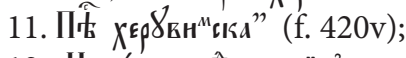

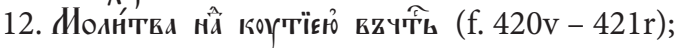

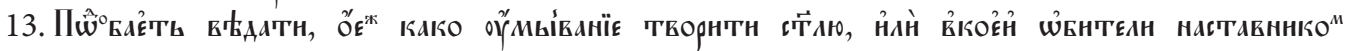
(f. 421r - 424r);

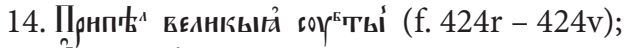

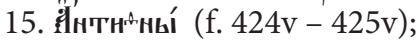

16. Мнраннана по́па погревстн гн̀це (f. 425v-426v);

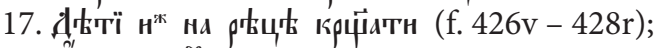

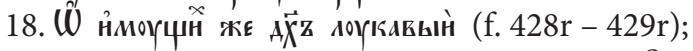

19. Тропарн вскенс вогрочны нпакон на Н̈ гаи́соิ (f. $430 \mathrm{r}-433 \mathrm{r}$ );

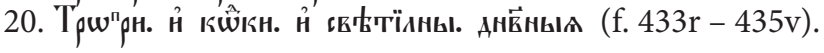




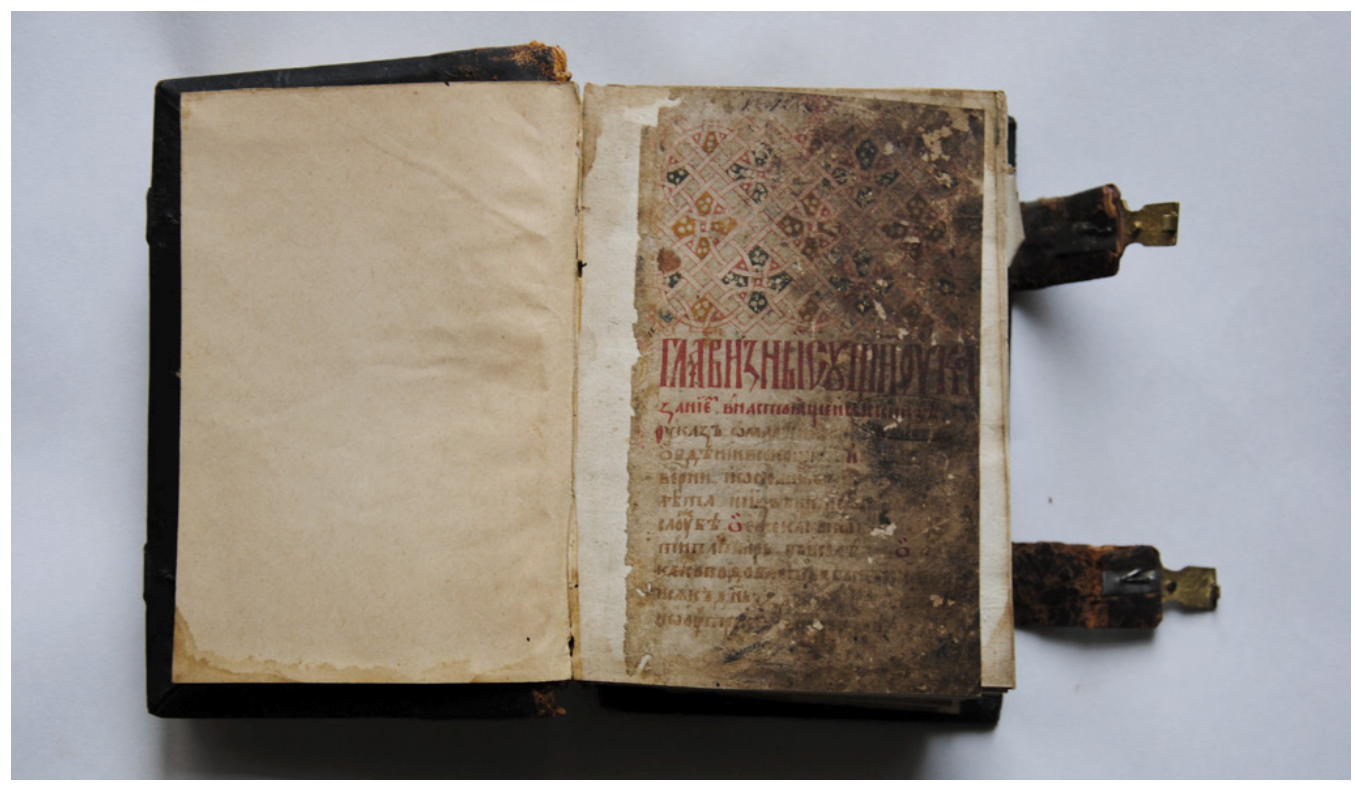

Fig. 1. Jerusalem Typikon, f. 1r. (NML, c. MC, n. u. 853)

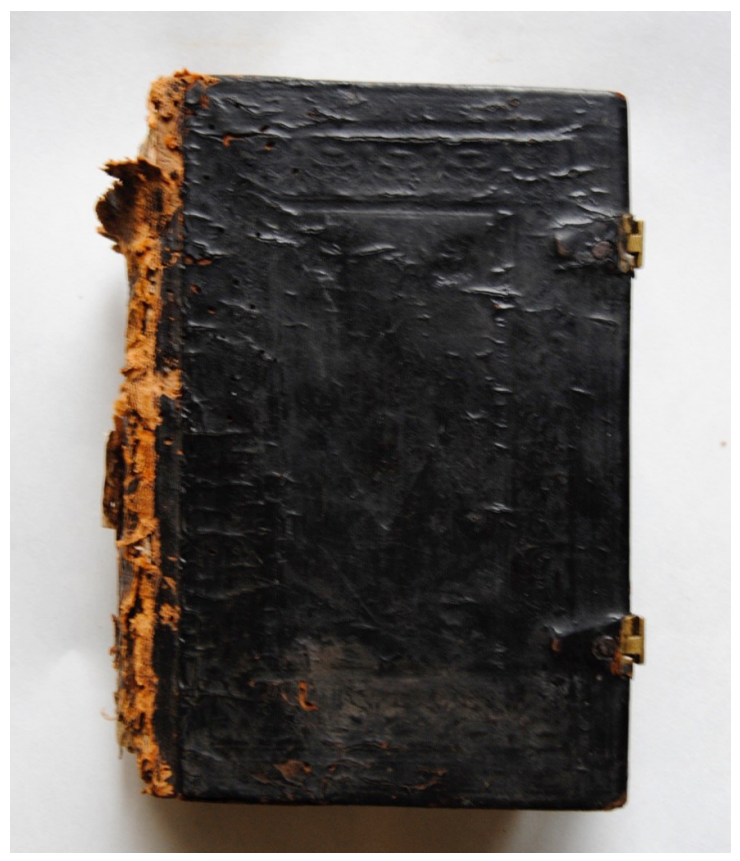

Fig. 2. Jerusalem Typikon, cover (NML, c. MC, n. u. 853) 